\title{
PERSEPSI GURU ATAS KEPEMIMPINAN SEKOLAH DAN KESEJAHTERAAN SEBAGAI PREDIKTOR KINERJA GURU
}

\author{
Oleh: \\ Heri Nurranto ${ }^{1}$ \\ Fadjriah Hapsari $^{2}$ \\ Muzdalifah $^{3}$ \\ Program Studi Pendidikan Ekonomi \\ Fakultas Ilmu Pendidikan dan Pengetahuan Sosial \\ Universitas Indraprasta PGRI \\ Email: heri.nurranto@gmail.com ${ }^{1}$
}

\begin{abstract}
ABSTRAK
Analisis ini bertujuan membuktikan serta mengetahui seberapa besar pengaruh persepsi guru atas kepemimpinan sekolah dan kesejahteraan terhadap kinerja guru, baik secara parsial maupun simultan. Sampel penelitian ini adalah 44guru SMP Negeri 9 Jakarta.Hasil penelitiandiperoleh persamaan regresi $\widehat{\mathbf{Y}}=26,259+$ $0,495 \mathrm{X}_{\mathbf{1}}+0,261 \mathrm{X}_{2}$.Uji hipotesismembuktikan bahwa persepsi guru atas kepemimpinan kepala sekolah berpengaruh terhadap Kinerja Guru, nilaI koefisien 0,495 dant-value 3,259. Kesejahteraanberpengaruh terhadap Kinerja Guru dengan nilai koefisien 0,261, t-value 3,390. Kepemimpinan Kepala Sekolah dan Kesejahteraan secara simultan berpengaruh terhadap Kinerja Guru dengan $F_{\text {hitung 16.626.R-square menunjukkan bahwa variabel persepsi guru atas }}$ kepemimpinan kepala sekolah dan kesejahteraan mampu menjelaskan perubahan kinerja guru sebesar $44,8 \%$.
\end{abstract}

Kata kunci :Persepsi Kepemimpinan Kepala Sekolah, Kesejahteraan dan kinerja guru.

\section{A. PENDAHULUAN}

Kemampuan dan jiwa kepemimpinan harus melekat erat pada seorang pemimpin. Gaya dan perilaku kepemimpinan seseorang pemimpin besar pengaruhnya terhadap tumbuh berkembangnya organisasi yang dipimpinnya. Secara spesifik, keberhasilan kepemimpinan secara terukur dapat dilihat dari dampaknya terhadap kinerja karyawan/pegawai yang dipimpinnya.

Kepala sekolah hendaknya memposisikan diri berada di antara para guru dan staf (working with a group), serta selalu mampu menumbuhkan semangat dan motivasi kerja setiap guru dan staf yang dipimpin.Kepala sekolah sebagai pimpinan sekolah sekaligus manajer sekolah, dituntut mampu mengelola dan mengarahkan seluruh sumber daya yang ada di sekolah, yaitu guru, karyawan serta siswa.

Kepala sekolah dituntut dapat menciptakan suasana kerja kondusif bagi guru dan karyawan, serta mampu menciptakan suasana nyaman dalam belajar dan menyenangkan bagi siswa-siswanya. Kepala sekolah juga harus bisa menumbuhkan 
semangat dan motivasi kerja bagi para guru serta motivasi belajar bagi para siswanya.

Desentralisasi pendidikan dengan otonomi sekolah, salah satu tujuannya adalah agar guru mampu menunjukkan kinerja optimal sehingga tercipta suatu kondisi pembelajaran aktif, kreatif, efektif dan menyenangkan. Terwujudnya kinerja guru sangat tergantung pada beberapa faktor, diantaranya kepemimpinan kepala sekolah, motivasi guru dan iklim serta lingkungan sekolah.

Setiap guru mempunyai kewajiban untuk menunjukkan kinerja melalui optimalisasi tugas pokok guru merencanakan program, melaksanakan program pengajaran dan membentuk pribadi siswa yang berkarakter. Peningkatan semangat kerja, kerjasama yang harmonis, perkembangan mutu guru, serta kinerja bawahan dapat ditentukan oleh kualitas kepemimpinan kepala sekolah. Oleh karena itu kepala sekolah hendaknya senantiasa mengembangkan diri untuk menjadi pemimpin pendidikan (education leader) yang profesional.

Kepemimpinan kepala sekolah yang efektif adalah kepemimpinan yang mampu menumbuhkembangkan dan memberdayakan segala sumberdaya beserta fasilitas yang ada guna mencapai tujuan, selain itu juga mampu menciptakan suasana atau iklim kerja yang nyaman dan menyenangkan. Untuk menciptakan iklim kerja kondusif, seorang kepala sekolah harus menunjukkan kemampuannya untuk mengendalikan organisasi, berperan sebagai integrator, koordinator, mediator dinamisator dan supervisor serta mampu berperan seebagai orang tua dan juga berperan sebagai pendidik.

Gaya kepemimpinan seorang kepala sekolah dinilai baik jika dalam memberikan tugas dan tanggung jawab kepada guru lebih menitikberatkan pada unsur mempengaruhi manusia/bawahan sehingga bawahan sanggup mengerjakan tugas dan tanggung jawabnya. Dalam teknik ini harus dihindari bentuk pemaksaaan kehendak dan ancaman berlebihan, karena kepala sekolah hanya memberikan ajakan atau bujukan kepada bawahan dengan disertai alasan rasional.

Pemberian kesejahteraan dipandang sebagai salah satu alat untuk memotivasi serta dapat digunakan sebagai jalur pengembangan strategis dalam meningkatkan kualitas sumber daya manusia yang dalam hal ini adalah guru. Program pemberian kesejahteraan, baik yang diberikan oleh pemerintah maupun oleh lembaga/ sekolah dimana seseorang bekerja merupakan bagian tidak terpisahkan dari suatu program kepegawaian untuk memberikan kesempatan serta perhatikan kebutuhan pribadi guru. Melalui hal tersebut diharapan guru dapat mengembangkan loyalitas, dedikasi serta keterampilan kerja secara efisien dan efektif.

Berdasarkan uraian di atas, penelitian ini menganalisis masalah persepsi guru atas gaya kepemimpinan kepala sekolah dan kesejahteraan serta pengaruhnya terhadap kinerja gurudi SMP Negeri 9 Jakarta

\section{B. KAJIAN PUSTAKA \\ Persepsi}

Persepi adalah sebuah proses individu mengorganisasikan dan mengintepretasikan kesan sensoris untuk memberikan pengertian pada lingkungannya (Robbins dan Judge, 2015:103). Apa yang kita nilai bisa jadi berbeda secara substansial dengan realitas objektif. 
Alport dalam Mar'at (2001:104) berpendapat bahwa“proses persepsi merupakan suatu proses kognitif yang dipengaruhi oleh pengalaman, cakrawala, dan pengetahuan individu". Suwarto (2010:53) menyatakan bahwa persepsi mencakup penafsiran objek, tanda dan orang dari sudut pengalaman yang bersangkutan, atau persepsi mencakup penerimaan stimulus, pengorganisasian stimulus dan penerjemahan.penafsiran stimulus yang telah diroganisasi dengan cara yang dapat mempengaruhi perilaku dan membentuk sikap.

Thoha (2003:54) berpendapat bahwa persepsi pada umumnya terjadi karena dua faktor, yaitu faktor internal dan faktor eksternal. Faktor internal berasal dari dalam diri individu, misalnya sikap, kebiasaan, dan kemauan. Sedangkan faktor eksternal adalah faktor-faktor yang berasal dari luar individu yang meliputi stimulus itu sendiri, baik sosial maupun fisik.

Dijelaskan oleh Robbins (2003:96) bahwa meskipun individu-individu memandang pada satu benda yang sama, mereka dapat mempersepsikannya berbeda-beda. Ada sejumlah faktor yang bekerja untuk membentuk dan terkadang memutar-balikkan persepsi, yaitu pelaku persepsi (perceiver), objek atau yang dipersepsikan serta konteks dari situasi dimana persepsi itu dilakukan.

Gilmer dalam Hapsari (2004:69) menyatakan bahwa persepsi dipengaruhi oleh berbagai faktor, antara lain faktor belajar, motivasi, dan pemerhati perseptor atau pemersepsi ketika proses persepsi terjadi. Adanya beberapa faktor bersifat subyektif yang mempengaruhinya, maka kesan yang diperoleh masing-masing individu akan berbeda satu sama lain.

Persepsi individu dipengaruhi oleh faktor fungsional dan struktural. Faktor fungsional ialah faktor-faktor yang bersifat personal, misalnya kebutuhan individu, usia, pengalaman masa lalu, kepribadian,jenis kelamin, dan hal-hal lain yang bersifat subjektif. Faktor struktural adalah faktor di luar individu, misalnya lingkungan, budaya, dan norma sosial sangat berpengaruh terhadap seseorang dalam mempresepsikan sesuatu.

Pada hakikatnya sikap adalah merupakan suatu interelasi dari berbagai komponen, Baron dan Byrne juga Myers dalam Gerungan (2006:47) menyatakan bahwa sikap itu mengandung tiga komponen yang membentuk struktur sikap, yaitu:

1. Komponen kognitif (komponen perseptual), yaitu komponen yang berkaitan dengan pengetahuan, pandangan, keyakinan, yaitu hal-hal yang berpengaruhdengan bagaimana orang mempersepsi terhadap objek sikap

2. Komponen afektif (komponen emosional), yaitu komponen yang berpengaruh dengan rasa senang/tidak senang terhadap objek sikap.

3. Komponen konatif (komponen perilaku/action component), yaitu komponen yang berpengaruhdengan kecenderungan bertindak terhadap objek sikap. Komponen konaktif juga menunjukkan besar kecilnya kecenderungan bertindak atau berperilaku seseorang terhadap objek sikap.

Sikap seseorang pada suatu obyek sikap merupakan manifestasi dari kontelasi ketiga komponen tersebut yang saling berinteraksi untuk memahami, merasakan dan berperilaku terhadap obyek sikap. Ketiga komponen itu saling berinterelasi dan konsisten satu dengan lainnya. 


\section{Guru}

Di dalam kamus Besar Bahasa Indonesia (2008 :497), guru ialah orang yang pekerjaannya (mata pencahariannya, profesinya) mengajar. Hamzah Uno (2008:15), menegaskan bahwa guru merupakan orang yang harus digugu dan ditiru, dalam arti orang yang memiliki kharisma atau wibawa yang perlu ditiru dan diteladani.

Seseorang disebut guru apabila memberitahukan sesuatu kepada siapapun. Memang, seorang guru adalah orang yang ditugaskan oleh suatu lembaga untuk memberikan ilmu pengetahuan kepada pelajar dan pada gilirannya dia memperoleh upah atau honor. Akan tetapi, di dalam beberapa risalah filsafat Al Ghazali, yang dikutip oleh Khan (2005:62) bahwa :

"Seseorang yang memberikan hal apa pun yang bagus, positif, kreatif, atau bersifat membangun kepada manusia yang sangat menginginkan, di dalam tingkat kehidupannya yang mana pun, dengan jalan apa pun, dengan cara apa pun, tanpa mengharapkan balasan uang kontan setimpal apa pun adalah guru atau ulama".

Dalam keseluruhan proses pendidikan, khususnya proses pembelajaran di sekolah dan madrasah, guru memegang peran utama dan amat penting. Perilaku guru dalam proses pendidikan dan belajar akan memberikan pengaruh dan corak yang kuat bagi pembinaan perilaku dan kepribadian anak didiknya. Oleh karena itu, perilaku guru hendaknya dapat dikembangkan sedemikian rupa sehingga dapat memberikan pengaruh baik kepada para anak didiknya.

\section{Kepemimpinan Kepala Sekolah}

Indrafachrudi (2006:2) mengartikan "Kepemimpinan adalah suatu kegiatan dalam membimbing suatu kelompok sedemikian rupa sehingga tercapailah tujuan itu". Kemudian menurut Ukas (2004:268) "Kepemimpinan adalah kemampuan yang dimiliki oleh seseorang untuk dapat mempengaruhi orang lain, agar ia mau berbuat sesuatu yang dapat membantu pencapaian suatu maksud dan tujuan". George R. Terry dalam Thoha (2003:5) mengartikan bahwa "Kepemimpinan adalah aktivitas untuk mempengaruhi orang-orang supaya diarahkan mencapai tujuan organisasi".

Kepala sekolah memiliki kepemimpinan yang berbeda dalam mempengaruhi para guru. Norma perilaku merupakan kriteria atau standar tingkah laku pemimpin, sehingga ia akan berperilaku dalam pola-pola tertentu.Menurut Gibson (2005:8990), "Perilaku individu di dalam organisasi, baik guru manajemen maupun non manajemen dipengaruhi oleh faktor-faktor yang menentukan, yakni faktor internal, faktor eksternal atau faktor lingkungan".Adapun penjelasan dari faktor-faktor tersebut di atas adalah sebagai berikut :

1. Faktor Internal

Faktor internal yaitu faktor yang datang dari diri seseorang pemimpin seperti kepribadian, pengalaman serta pendidikan dan latihan.

Kepribadian adalah keseluruhan cara yang digunakan seseorang untuk bereaksi dan berinteraksi dengan orang lain. Pengalaman merupakan pelajaran 
yang dipetik seseorang dari peristiwa-peristiwa yang dilalui selama perjalanan hidupnya.

Dalam bidang pendidikan kemampuan kognitif, afektif dan psikomotorik memperoleh perhatian seimbang, sehingga hasil pendidikan lebih bersifat filosofis dan teoritis. Sedangkan pelatihan merupakan bagian dari proses pendidikan yang bertujuan meningkatkan kemampuan atau keterampilan khusus.

2. Faktor Eksternal

Faktor eksternal adalah faktor yang datang dari luar diri seperti karakteristik personal dan kondisi lingkungan.Karakteristik personal, yang meliputi kepribadian, pendidikan pengalaman, masa kerja, usia, jenis kelamin dan lain-lainnya dan dapat mempengaruhi terhadap gaya kepemimpinan.

Dalam melaksanakan fungsinya sebagai seorang pemimpin, kepala sekolah sebagai administrator harus memahami dan menguasi kecakapan dan fungsi yang seharusnya dimiliki seorang pemimpin. Kepala sekolah sebagai pemimpin di lembaga pendidikan mempunyai fungsi penting. Fungsi kepemimpinan menurut Nawawi (1993:41) yaitu sebagai berikut:

1. Fungsi instruktif adalah tungsi yang dimiliki oleh kepala sekolah dalam memberikan perintah yang bersifat komunikatif, agar dilaksanakan oleh guru sehingga menjadi kegiatan bagi yang menerimanya. Instruksi/perintah yang diberikan harus komunikatif, mudah dipahami atau dimengerti dengan jelas oleh orang yang diperintah.

2. Fungsi konsultatif berbeda dengan fungsi instruktif yang bersifat satu arah, dan konsultatif bersifat dua arah dengan bentuk interaksi antara pemimpin dan anggota. Namun demikian tingkat intensitas dan efektifitasnya sangat tergantung pada pemimpin. Guna memudahkan pelaksanaanya pemimpin hendaknya memperhatikan berbagai persoalan, aspirasi, pendapat data, dan informasi yang diberikan anggota dalam menetapkan keputusan. Di samping itu pemimpin juga harus memperhatikan umpan balik atau umpan balik dalam rangka memperbaiki keputusan-keputusan yang telah diambil.

3. Fungsi Partisipasi lebih intens dari fungsi konsultatif dan merupakan perwujudan pengaruhmanusiawi yang komplek. Pemimpin harus mampu mendorong anggota/bawahan dalam menjalankan tugas pokoknya, berkomunikas horizontal maupun vertikal. Pelaksanaan fungsi partisipasi juga berarti kesediaan pemimpin untuk turut serta dalam berbagai keputusan tetapi buka untuk hal yang bersifat teknis operasional.

4. Fungsi delegasi dilakukan dengan melimpahkan sebagian wewenang kepada staf pimpinan yang membantunya. Baik dengan persetujuan pucuk pimpinan maupun tanpa persetujuan pimpinan yang terbatas pada bidang-bidang yang non principle

5. Fungsi pengendalian bersifat satu arah meski seharusnya lebih efektif bila dilakukan dengan komunikasi dua arah. Pelaksanaan fungsi pengendalian dapat dilakukan melalui bimbingan kerja yang dapat dilakukan pada saat kegiatan berlangsung sebagai upaya mencegah terjadinya penyimpangan atau kekeliruan dalam menjalankan perintah atau keputusan. 
6. Fungsi keteladanan merupakan fungsi kepemimpinan yang menjadi contoh bagi para bawahan dalam melaksanakan pekerjaannya, mengingat pemimpin adalah orang pertama yang melaksanakan peraturan dan keputusan yang dibuatnya.

Menurut Indrafachrudi (2003:67), kepemimpinan dalam rangka inovasi pendidikan dar pertumbuhan jabatan guru dan tanggung jawab dapat digolongkan menjadi tiga bidang, yaitu : "a) tugas dalam bidang manajerial, b) tugas dalam bidang administrasi c) tugas dalam evaluasi" Tugas dalam bidang manajerial, kepala sekolah harus mampu menetukan arah dan tujuan dengan cara menggerakan sumber-sumber yang ada, baik sumber daya manusia maupun sumber daya material, mengawas proses dan meningkatkan standar organisasi melalui kegiatankegiatan fungsi manajemen.

Tugas di bidang administrasi, kepala sekolah melaksanakan administrasi yang berkaitan dengan kegiatan-kegiatan pengelolaan, pengajaran, pengelolaan siswa, pengelolaan kepegawaian dan pengelolaan keuangan.Pengelolaan pengajaran antara lain kebutuhan tenaga guru, pembagian tugas mengajar, pengadaan buku dan alat pelajaran, peraga, pengadaan atau pengembangan laboratorium, perpustakaan, sistem penilaian hasil belajar, kegiatan kokurikuler dan lain-lain.Pengelolaan siswaantara lain prosedur penerimaan siswa baru, pengelompokkan siswa/pembagian kelas, bimbingan dan konseling siswa, pelayanan kesehatan murid dan sebagainya.

Pengelolan kepegawaian mencakup penerimaan dan penempatan guru/ pegawai baru, pembagian tugas/pekerjaan guru dan pegawai sekolah, usaha kesejahteraan guru/pegawai sekolah, mutasi atau promosi guru/ pegawai sekolah dan sebagainya.Pengelolaan keuangan mencakup pengadaan dan pengelolaan keuangan untuk berbagai kegiatan yang telah direncanakan baikoleh pemerintah atau dari POMG/BP-3 maupun sumber-sumber lainnya.

\section{Gaya Kepemimpinan Kepala Sekolah}

Menurut Indriyo dalam Danang Sunyoto (2013:38) gaya perilaku pemimpin terbagi menjadi empat;

1. Perilaku instrumental yang meliputi perencanaan, pengorganisasian, pengendalian dan koordinasi dari kegiatan bawahan oleh pemimin. Pemimpin menekankan pada pemahaman bawahan akan apa yang diharapkan padanya oleh pemimpin.

2. Perilaku suportif yang meliputi memberikan pertimbangan terhadap kebutuhan dari bawahan, menunjukkan perhatiannya pada kesejahteraan dan menciptakan lingkungan yang menyenangkan.

3. Perilaku partisipatif yaitu perilaku pemimpin yang bercirikan adanya pemberian informasi dan menekankan pada konsultasi dengan bawahan dan menggunakan gagasan bawahan dalam memutuskan keputusan yang berkaitan dengannya.

4. Gaya berorientasi prestasi yang meliputi penetapan tugas-tugas menantang dengan harapan agar bawahan bekerja dengan tingkat prestasi yang tinggi dan secara terus menerus berupaya meningkatkan prestasi.

Menurut Gibson (2005:144) bahwa perbedaan gaya kepemimpinan yang 
dipilih seorang manajer juga dipengaruhi oleh bagaimana manajer tersebut memandang orang-orang. Pada konteks kepemimpinan kepala sekolah, menurut Indrafachrudi (2003:37), kepala sekolah sebagai pemimpin harus memiliki keterampilan yaitu 1) mengenal dan mengetahui kekuatan, kelemahan, dan kekurangan staffnya, 2) menanamkan serta memelihara sikap percaya mempercayai dalam kelompok, 3) menanamkan dan membina disiplin kelompok, 4) menanamkan dan memupuk sifat bersedia menolong antara anggota kelompok, 5) memperbesar rasa tanggung jawab kepada anggota kelompok, 6)mempergunakan kebijaksanaan untuk mengatasi masalah atau pertentangan yang mungkin timbul, 7) memimpin rapat-rapat, "workhsop" atau "in-service training”, 8) mengatur waktu sebaik-baiknya, dan 9). mencari konsensus atau mempersatukan.

Keterampilan-keterampilan tersebut merupakan hal yang harus dimiliki pemimpin dalam pengaruhnya dengantugasnya yaitu agar mampu menguasai kelompok/bawahannya. Jika salah satu dari keterampilan tersebut tidak dimiliki oleh seorang pemimpin, maka dalam mengarahkan bawahannya akan terjadi kepincangan.

\section{Kesejahteraan}

Menurut Maier (2002 : 92), sistem upah pada umumnya dipandang sebagai suatu alat untuk mendistribusikan upah kepada guru. Distribusi upah tersebutdapat berdasarkan pada jumlah produksi, lama bekerja/dinas serta berdasarkan kebutuhan hidup.

Sistem upah pada dasarnya sama dengan semua jenis atau bentuk sistem, tetapi dasar-dasar pendistribusian tidak harus sama. Misalnya saja sistem upah menurut produksi, maka pendistribusian upah juga menurut jumlah prestasi yang dicapai melalui satuan-satuan produksi tertentu. Apabila sistem upah menurut lamanya dari jumlah waktu yang dipergunakan untuk menyelesaikan suatu tugas, diantaranya ada yang disebut upah harian, upah mingguan, upah bulanan dan lainlain. Sistem upah menurut lamanya dinas, menghargai guru berdasarkan pada lamanya dinas, dan sistem upah menurut kebutuhan, mendistribusikan upah sesuai dengan biaya kebutuhan pokok.

Dari beberapa definisi di atas, maka upah merupakan penghargaan kepada guru yang dimanifestasikan sebagai hasil produksi atau suatu jasa yang dianggap sama dengan itu, yang berupa uang, tanpa suatu jaminan pasti dalam tiap-tiap minggu atau bulan.Maka hakekat upah adalah suatu penghargaan dari energi guru yang dimanifestasikan dalam bentuk uang.

Menurut Maier (2002:94), ada empat sistem upah yang secara umum dapat diklasifikasikan yaitu sistem upah menurut banyaknya produksi, sistem upah menurut lamanya bekerja, sistem upah menurut lamanya dinas dan sistem upahmenurut kebutuhan.

Halsey dalam Hasibuan (1992:45) menguraikan beberapa syarat untuk dipenuhi berkaitan dengan rencana dan sistem upah yang baik, yaitu:

1. Adil bagi pekerja dan pimpinan perusahaan. Artinya guru jangan sampai dijadikan alat pemerasan dalam mengejar angka-angka produksi guru.

2. Sistem upah sebaiknya bisa mempunyai potensi untuk mendorong semangat kerja guru dalam produktivitas kerja. 
3. Selain upah dasar (standar) perlu disediakan pula upah perangsang sebagai imbalan tenaga yang dikeluarkan oleh guru.

4. Sistem upah itu sebaiknya harus mudah dimengerti artinya jangan berbelit-belit sehingga guru akan sulit memahaminya. Ini penting untuk menghilangkan adanya kesan prasangka bagi guru terhadap perusahaan.

Berdasarkan beberapa teori di atas, upah merupakan alat yang digunakan untuk meningkatkan kesejahteraan, sekalipun bukan segala-galanya, sedangkan kesejahteraan selalu menjadi motivasi bagi setiap individu untuk melakukan berbagai aktivitas. Oleh karena itu dalam konteks peningkatan kinerja guru gaya kepemimpinan kepala sekolah senantiasa berkaitan dengan kesejahteraan guru, hal tersebut baik secara langsung maupun tidak langsung dapat menentukan motivasi guru dalam bekerja.

\section{Kinerja Guru}

Manajemen kinerja meliputi seluruh kegiatan yang dilakukan dalam sebuah proses manajemen yang dimulai dari menetapkan tujuan dan sarsaran yang ingin dicapai, pembuatan rencana, pengorganisasian, penggerakan/pengarahan dan akhirnya evaluasi atas hasilnya sebagai kinerja (Herawan dan Hartini, 2013:242). Kinerja adalah hasil kerja secara kualitas dan kuantitas yang dicapai oleh seorang pegawai dalam melaksanakan tugas sesuai dengan tanggung jawab yang diberikan (Mangkunegara, 2001:67)

Tinggi rendahnya kinerja berkaitan erat dengan sistem pemberian penghargaan yang diterapkan oleh lembaga/organisasi tempat mereka bekerja. Berkaitan dengan kinerja guru dalam melaksanakan tugasnya sehari-hari, perlu memiliki tiga kemampuan dasar agar kinerjanya tercapai, yakni sebagai berikut:

1. Kemampuan pribadi meliputi hal-hal yang bersifat fisik seperti tampang, suara, mata atau pandangan, kesehatan, pakaian, pendengaran, dan hal yang bersifat psikis seperti humor, ramah, intelek, sabar, sopan, rajin, kreatif, kepercayaan diri, optimis, kritis, obyektif, dan rasional;

2. Kemampuan sosial antara lain bersifat terbuka, disiplin, memiliki dedikasi, tanggung jawab, suka menolong, bersifat membangun, tertib, bersifat adil, pemaaf, jujur, demokratis, dan cinta anak didik;

3. Kemampuan profesional sebagaimana dirumuskan oleh P3G yang meliputi 10 kemampuan profesional guru yaitu: menguasai bidang studi dalam kurikulum sekolah dan menguasai bahan pendalaman/ aplikasi bidang studi, mengelola program belajar mengajar,mengelola kelas, menggunakan media dan sumber, menguasai landasan-landasan kependidikan, mengelola interaksi belajar mengajar, menilai prestasi siswa untuk kepentingan pendidikan, mengenal fungsi dan program bimbingan penyuluhan, mengenal dan menyelenggarakan administrasi sekolah, memahami prinsip dan menafsirkan hasil-hasil penelitian pendidikan guna keperluan mengajar.

Kinerja guru dalam proses belajar mengajar adalah kemampuanguru dalam melaksanakan tugasnya sebagai pengajar yang memilikikeahlian mendidik siswa dalam rangka membina peserta didikuntuk tercapainya institusi pendidikan.Kinerja 
dan hasil kerja selalu merupakan tanda keberhasilan organisasi dan orang-orang yang ada dalam organisasi tersebut.

Dari berbagai acuan tersebut maka dalam penelitian ini menggunakan istilah kinerja atau prestasi kerja sebagai terjemahan dari kata performance. Jadi yang dimaksud terhadap kinerja adalah cara, usaha dan hasil kerja yang dapat dicapai oleh seseorang atau sekelompok orang dalam suatu organisasi, sesuai dengan wewenang dan tanggung jawab masing-masing dalam upaya mencapai tujuan organisasi bersangkutan secara tegas, tidak melanggar hukum dan sesuai dengan moral maupun etika. Kinerja guru dalam pekerjaannya harus dirumuskan secara jelas dan dikomunikasikan secara terbuka.Bila manajemen kinerja dipergunakan dengan tepat akan berdampak pada berbagai keuntungan yang dapat diperoleh perusahaan.

Performance model Vroom yang disebut expectancy theory (Sirait, 206:250) menjelaskan bahwa produktivitas/prestasi seseorang tergantung pada motivasi orang tersebut terhadap pekerjaan yang dilakukan. Semakin tinggi motivasi seseorang untuk melakukan pekerjaan, semakin tinggi pula tingkat produktivitasnya, dengan anggapan bahwa kemampuan orang tersebut tidak berubah. Model expectancy theory ini dirumuskan secara matematis $\mathrm{P}=\mathrm{MXA}$, dimana $\mathrm{P}$ adalah performance, $\mathrm{M}$ adalah motivation dan $\mathrm{A}$ adalah ability.

Menurut penelitian Official End of Millennium State of HR Survey (Ivancevich dalam Budihardjo, 2011:76-77), agar aktivitas aktivitas sumber daya manusia dapat dijalankan dengan optimal, para profesional harus memiliki kompetensi antara lain communication skills, problem solving, leadership, recruiting/satffing, employment law, training and development, tecnology, forecasting, compensation design, benefits design accounting/finance and record keeping. Sementara ini menurut Zweel (Budihardjo:77) memeringkat kompetensikompetensi untuk membedakan karyawan berprestasi unggul dengan mereka yang berprestasi rata-rata yaitu influence, result orientation, initiative, interpersonal awareness, service orientation, integrity and truth, relationship building, analitical thinking, conceptual thinking, information gathering dan organizational savvy.

Menurut Peraturan Pemerintah No. 19 tahun 2005 pasal 28, untuk menjadi guru selain memenuhi persayarat adminitratif juga harus memenuhi syarat kompetensi yaitu kompetensi pedagogik, kompetensi profesional, kompetensi sosial dan kompetensi kepribadian.

Maka kinerja dapat dipahami secara utuh yaitu mampu melaksanakan tugastugas pokok dan fungsinya sebagai educator, trainer, teacher, coacher, serta mampu melaksanakan kewajiban profesional yakni merancang program pembelajaran, mengelola proses pembelajaran, menyelenggarakan evaluasi, menyelenggarakan perbaikan (remedial teaching), dan menyelenggarakan pengayaan (enrichment), dan juga memiliki kesetiaan (loyalitas), berdisiplin tinggi, berinisiatif, dan memiliki jiwa kepemimpinan.

\section{METODE PENELITIAN}

Penelitian ini bersifat deskriptif kuantitatif melalui langkah perumusan hipotesis, pengelompokkan dan tabulasi data, penyajikan data dari tiap 
variabelserta melakukan analisis untuk menjawab permasalahan dan pengujian hipotesis. Langkah selanjutnya adalah melakukan pembahasan deskriptif atas dasar hasil penelitian empiris.

Data penelitian ini adalah data primer yang diperoleh dari kuesioner 44 guru SMP Negeri 9 Jakarta atas indikator-indikator yang mengukur variabel persepsi guru atas kepemimpinan kepala sekolah, kesejahteraan guru dan kinerja guru yang dijelaskan dengan variabel penelitian berikut.

1. Variabel Dependen penelitian ini adalah kinerja guru, yang diukur melalui indikator kemampuan merencanakan belajar mengajar, melaksanakan kegiatan belajar mengajar dan Kemampuan mengevaluasi proses pembelajaran

2. Variabel Independen penelitian ini terdiri dari dua variabel, pertama Persepsi guru atas kepemimpinan kepala sekolah yang dikur melalui indikator kemampuan kepribadian, Kemampuan mendidik, Kemampuan melaksanakan tugas pokok dan fungsi guru dan Kemampuan kemasyarakatandan kedua adalah variabel Kesejahteraan guru yang diukur melalui indikator kesempatan untuk maju, gaji dan insentif, pengawasan (supervisi) dan faktor instrinsik.

Tujuan penelitian ini adalah untuk mengetahui hubungan korelasional sebab akibat antar variabelkepemimpian kepala sekolah, kesejahteraan dan kinerja guru. Analisis yang digunakan adalah pendekatan regresi linear berganda. Uji hipotesis untuk mengetahui pengaruh variabel independen secara parsial digunakan pendekatan uji t sedangkan untuk mengetahui pengaruh variabel dependen secara simultan digunakan uji F.

\section{HASIL DAN PEMBAHASAN}

Persyaratan uji analisis dalam penelitian ini yaitu uji normalitas data, multikolineritas, heterokedastisitas, otokorelasiuji linieritas garis regresi. Kriteria pengujian normalitas data adalah jika $p$ value $\left(\right.$ sig) $>0.05$ maka $\mathrm{H}_{0}$ diterima artinya data pada sampel tersebut berdistribusi normal. Hasil normalitas data dengan uji KS padaAsymp Sig two tailed adalah $X_{1}=0,200$ dan $X_{2}=0,200$, sehingga karena seluruh variabel mempunyai koefisien > dari $\alpha 5 \%(0,05)$ maka dinyatakan bahwa data berasal dari populasi yang berdistribusi normal.

VIF variabel Persepsi Guru atas Kepemimpinan Kepala Sekolah bernilai 1,126 pada toleran 0,888 dan variabel Kesejahteraan 1,126 pada toleran 0,888. Jadi seluruh variabel independen mempunyai dalam VIF berkisar pada angka 1 sehingga data tidak terjadi gangguan multikolineritas.

Uji asumsi heteroskedastisitas digunakan untuk mengetahui apakah variasi residual absolut sama atau tidak sama untuk semua pengamatan, pendekatan yang digunakan adalah Spearman Correlations. Dari hasil analisis data disimpulkan bahwa seluruh variabel dalam penelitian ini tidak terdapat heterokedatisitas karena nilai sign lebih besar dari pada 0,005, yaitu Persespi Guru atas Kepemimpinan Kepala Sekolah 0,840 dan Kesejahteraan Guru 0,855.

Uji otokorelasi digunakan dalam penelitian ini adalah uji Durbin-Watson pada taraf kepercayaan $95 \%$ atau $\alpha \quad 5 \%(0,05)$ dengan variabel bebas $(\mathrm{k}=2)$ menunjukkan bahwa DW hitung $>\mathrm{dL}(1,908>1,423)$ maka model regresi 
dalam penelitian ini tidak mengalami autokorelasi. Sehingga telah memenuhi uji persyaratan regresi linear ganda.

Dari hasil perhitungan regresi dengan SPSS 22 seperti pada table Coefficients ${ }^{a}$, dapat ditentukan persamaan regresi yaitu :

$\mathrm{Y}=26.259+0,495 \mathrm{X} 1+0,261 \mathrm{X} 2$

Tabel 1. Coefficients ${ }^{a}$

\begin{tabular}{|c|c|c|c|c|c|c|}
\hline \multirow{2}{*}{\multicolumn{2}{|c|}{ Model }} & \multicolumn{2}{|c|}{ Unstandardized Coefficients } & \multirow{2}{*}{$\begin{array}{c}\text { Standardized } \\
\text { Coefficients } \\
\text { Beta }\end{array}$} & \multirow[b]{2}{*}{$\mathrm{t}$} & \multirow[b]{2}{*}{ Sig. } \\
\hline & & B & Std. Error & & & \\
\hline \multirow[t]{3}{*}{1} & (Constant) & 26.259 & 13.277 & & 1.978 & .055 \\
\hline & $\begin{array}{l}\text { Persepsi } \\
\text { Kepemimpinan }\end{array}$ & .495 & .152 & .401 & 3.259 & .002 \\
\hline & Kesejahteraan & .261 & .077 & .418 & 3.390 & .002 \\
\hline
\end{tabular}

Tabel 2. Coefficients ${ }^{b}$

\begin{tabular}{|l|l|r|r|r|r|r|}
\hline \multirow{2}{*}{ Model } & \multicolumn{3}{|c|}{ Correlations } & \multicolumn{2}{c|}{ Collinearity Statistics } \\
\cline { 3 - 7 } & Zero-order & Partial & Part & Tolerance & \multicolumn{1}{c|}{ VIF } \\
\hline \multirow{3}{*}{1} & (Constant) & & & & & \\
\cline { 2 - 7 } & Persepsi Kepemimpinan & .541 & .454 & .378 & .888 & 1.126 \\
\cline { 2 - 7 } & Kesejahteraan & .552 & .468 & .393 & .888 & 1.126 \\
\hline & & & & & & \\
\hline
\end{tabular}

Hasil uji t yang dilakukan adalah uji dua arah maka yang dibaca adalah t 1/2 $(0,05)$ atau $t(0,025)$, sehingga besarnya $t_{\text {tabel }}=2,0195$. Berdasarkan hasil perhitungan menggunakan SPSS 22, maka dapat diketahui besarnya t-hitung sebagai berikiut :

$$
\begin{aligned}
& t_{\text {tabel }}=2,0195 \\
& t_{\text {hitung }} \mathrm{X}_{1}=3.259 \\
& t_{\text {hitung }} \mathrm{X}_{2}=3.390
\end{aligned}
$$
berikut :

Dari hasil-hasil di atas maka dapat di ambil keputusan hipotesis sebagai

1. Variabel Persepsi Guru atas Kepemimpinan Kepala Sekolah $\left(\mathrm{X}_{1}\right)$, Oleh karena $t_{\text {hitung }}>t_{\text {tabel }}(3,259>2,0195)$, maka Ho ditolak, artinya ada pengaruh persepsi guru atas kepemimpinan kepala sekolah terhadap kinerja guru.

2. Variabel Kesejahteraan $\left(\mathrm{X}_{2}\right)$, oleh karena $t_{\text {hitung }}>t_{\text {tabel }}(3,390>2,0195)$, Maka Ho ditolak, artinya bahwa ada pengaruh kesejahteraan terhadap kinerja guru.

3. Hasil uji $\mathrm{F}$ menunjukkan bahwa besarnya $F_{\text {hitung }}=16.626$ sedangkan $F_{\text {tabel }}$ dapat dilihat pada $\alpha 0,05$ atau taraf keyakinan $95 \%$ dengan derajat bebas pembilang $=(\mathrm{k}-1)=3-1=2$. Derajatpenyebut $=(\mathrm{n}-\mathrm{k})=44-3=41$, $F_{\text {tabel }} 0,05(2 ; 41)=3,23$. Sehingga dalam penelitian ini $F_{\text {hitung }}>F_{\text {tabel }}(16.626$ $>3,23$ ). Dari hasil ini disimpulkan bahwapersepsi guru atas kepemimpinan kepala sekolah dan kesejahteraan secara bersama-sama berpengaruh secara signifikan terhadap kinerja guru SMP Negeri 9 Jakarta, sedangkan dilihat dari 
probabilitasnya lebih kecil dari taraf signifikansi 0,05 maka model yang digunakan dalam penelitian ini dapat diterima.

Makna dari persamaan regresi $\mathrm{Y}=26.259+0,495 \mathrm{X} 1+0,261 \mathrm{X} 2$ yang dihasilkan dari penelitian ini adalah sebagai beikut :

1. Konstanta $(a)=26,259$, artinya tanpa adanya persepsi guru atas kepemimpinan kepala sekolah dan kesejahteraaan atau kedua variabel tersebut konstan tidak ada perubahan maka besarnya tingkat kinerja guru adalah 26,259.

2. Koefisien regresi $X_{1}\left(b_{1}\right)=0,495$, artinya persepsi guru atas kepemimpinan kepala sekolah memiliki pengaruh positif terhadap kinerja guru, artinya jika persepsi guru atas kepemimpinan kepala sekolah meningkat per satu satuan maka tingkat kinerja guru meningkat sebesar 0,495.

3. Koefisien regresi $X_{2}\left(b_{2}\right)=0,261$, artinya kesejahteraan memiliki pengaruh positif terhadap kinerja guru, artinya jika Kesejahteraan meningkat per satu satuan maka tingkat kinerja guru akan naik sebesar 0.261.

Tabel 3. ANOVA
\begin{tabular}{|l|l|r|r|r|r|r|}
\hline \multirow{2}{*}{ Model } & \multicolumn{1}{c|}{$\begin{array}{l}\text { Sum of } \\
\text { Squares }\end{array}$} & df & Mean Square & F & Sig. \\
\hline 1 & Regression & 2135.027 & 2 & 1067.514 & 16.626 & $.000^{\mathrm{b}}$ \\
\cline { 2 - 8 } & Residual & 2632.518 & 41 & 64.208 & & \\
\cline { 2 - 8 } & Total & 4767.545 & 43 & & & \\
\hline
\end{tabular}

a. Dependent Variable: Kinerja Guru

b. Predictors: (Constant), Kesejahteraan, Persepsi Kepemimpinan

Tabel 4. Model Summary

\begin{tabular}{|c|c|c|c|c|c|c|c|c|}
\hline \multirow[b]{2}{*}{ Model } & \multirow[b]{2}{*}{$\mathrm{R}$} & \multirow[b]{2}{*}{ R Square } & \multirow[b]{2}{*}{$\begin{array}{l}\text { Adjusted } \\
\text { R Square }\end{array}$} & \multirow{2}{*}{$\begin{array}{l}\text { Std. Error } \\
\text { of the } \\
\text { Estimate }\end{array}$} & \multicolumn{3}{|c|}{ Change Statistics } & \multirow[b]{2}{*}{$\begin{array}{l}\text { Durbin- } \\
\text { Watson }\end{array}$} \\
\hline & & & & & $\begin{array}{c}\text { R Square } \\
\text { Change }\end{array}$ & 1.908 & df1 & \\
\hline 1 & $.669^{a}$ & .448 & .421 & 8.013 & .448 & 16.626 & 2 & 1.908 \\
\hline
\end{tabular}

Pada perhitungan koefisien determinasi, diperoleh $\mathrm{R}^{2}$ yaitu $44,8 \%$ artinya bahwa variabel persepsi guru atas kepemiminan kepala sekolah dan kesejahteraan mampu menjelaskan perubahan tingkat kinerja guru sebesar $44,8 \%$ sedangkan $55,2 \%$ sisanya dijelaskan oleh variabel-variabel lainnya yang tidak diteliti dalam penelitian ini.

Menurut sintesis teori seperti yang diuraikan pada bagian sebelumnya, persepsi guru atas gaya kepemimpinan kepala sekolah adalah tanggapan guru sebagai bawahannya dengan kepemimpinan kepala sekolah sebagai pemimpin dalam unit organisasi sekolah yang dapat menentukan baik buruknya kinerja guru yang bersangkutan. Sedangkan kinerja guru berkaitan dengan penampilan guru secara utuh yang mampu melaksanakan tugas-tugas pokok dan fungsinya; edukator, trainer, teacher, coacher, serta mampu melaksanakan kewajiban profesional yakni merancang program pembelajaran, mengelola proses pembelajaran, menyelenggarakan evaluasi, menyelenggarakan perbaikan (remedial teaching), dan menyelenggarakan pengayaan(enrichment), dan juga memiliki kesetiaan (loyalitas), berdisiplin tinggi, berinisiatif, dan memiliki jiwa kepemimpinan. 
Dari teori tersebut maka dapat dipahami bahwa jika kepala sekolah bisa menjalankan semua tugas dan fungsinya dengan baik, maka guru akan mempunyai persepsi yang baik terhadap kepala sekolah, sehingga guru juga akan melaksanakan tugas dan fungsinya dengan baik. Jika guru bisa melaksanakan tugas dan fungsinya dengan baik maka akan diperoleh hasil kerja yang baik pula, dan jika seseorang atau sekelompok orang memperoleh hasil yang baik maka dapat dikatakan bahwa orang atau sekelompok orang tersebut mempunyai kinerja yang baik.

Kesejahteraan adalah hal yang sangat dibutuhkan oleh guru, baik dalam bentuk material maupun non material, sehingga guru yang bersangkutan termotivasi untuk melakukan upaya dan ikhtiarnya dalam meraih semua harapannya itu.Jika semua kebutuhan guru telah terpenuhi maka secara psikologis, guru tersebut akan lebih tenang dan bisa lebih berkonsentrasi dalam bekerjakarena tidak lagi terbebani dengan masalah pemenuhan hajat hidupnya dan pemenuhan kebutuhan-kebutuhan penunjang lainnya. Di samping itu akan tumbuh motivasi yang kuat untuk meningkatkan kualitas kerjanya. Jika seseorang atau sekelompok orang bekerja dengan kosentrasi dan motivasi yang tinggi maka niscaya akan memperoleh hasil yang baik, dan jika seseorang atau sekelompok orang memperoleh hasil yang baik maka dapat dikatakan bahwa orang atau sekelompok orang tersebut mempunyai kinerja yang baik. Dengan kata lain bahwa semakin tinggi tingkat kesejahteraan guru maka kinerja guru tersebut juga akan semakin tinggi.

Persepsi guru atas gaya kepemimpinan kepala sekolah adalah tanggapan guru sebagai bawahannya dengan kepemimpinan kepala sekolah sebagai pemimpin dalam unit organisasi sekolah yang dapat menentukan baik buruknya kinerja guru yang bersangkutan, dan kesejahteraan guru adalah hal yang sangat dibutuhkan oleh guru, baik dalam bentuk material maupun non material, sehingga guru yang bersangkutan sehingga termotivasi untuk melakukan upaya dan ikhtiarnya dalam meraih semua harapannya itu. Sedangkan Kinerja guru berkaitan dengan penampilan guru secara utuh yang mampu melaksanakan tugas-tugas pokok dan fungsinya; edukator, trainer, teacher, coacher, serta mampu melaksanakan kewajiban profesional yakni merancang program pembelajaran, mengelola proses pembelajaran, menyelenggarakan evaluasi, menyelenggarakan perbaikan (remedial teaching), dan menyelenggarakan pengayaan (enrichment), dan juga memiliki kesetiaan (loyalitas), berdisiplin tinggi, berinisiatif, dan memiliki jiwa kepemimpinan.

Dari uraian intepretasi hipotesis pertama diperoleh kesimpulan bahwa jika kepala sekolah bisa menjalankan semua tugas dan fungsinya tersebut dengan baik, maka guru akan mempunyai persepsi yang baik dengan kepala sekolah, sehingga guru juga akan melaksanakan tugas dan fungsinya dengan baik. Jika guru bisa melaksanakan tugas dan fungsinya dengan baik maka akan diperoleh kinerja yang baik pula, atau dengan kata lain bahwa semakin baik persepsi guru atas gaya kepemimpinan kepala sekolah maka kinerja guru tersebut juga akan baik dengan koefisien pengaruh sebesar 0,495.

Dari uraian intepretasi hipotesis kedua dipeoleh kesimpulan bahwa jika semua kebutuhan guru telah terpenuhi maka secara psikologis akan guru tersebut akan lebih tenang dan bisa lebih berkonsentrasi dalam bekerja, serta akan tumbuh 
motivasi yang kuat dari dalam diri guru untuk meningkatkan kinerjanya, atau dengan kata lain bahwa semakin tinggi tingkat kesejahteraan guru maka kinerja guru tersebut juga akan semakin tinggi dengan koefisien pengaruh sebesar 0,261.

Secara keseluruah disimpulkan bahwa semakin tinggi persepsi guru atas gaya kepemimpinan kepala sekolah maka kinerja guru meningkat dan jika semakin tinggi tingkat kesejahteraan guru maka kinerja guru juga semakin tinggi. Secara bersama-sama semakin tinggi persepsi guru atas gaya kepemimpinan kepala sekolah dan semakin tinggi kesejahteraan guru akan berakibat semakin tinggi pula kinerja guru.

\section{E. SIMPULAN}

Berdasarkan deskripsi dan hasil analisis data maka dapat disimpulkan :

1. Pengujian hipotesis parsial dengan pendekatan uji t menunjukkan bahwa besarnya $t_{\text {hitung }}>t_{\text {tabel }}(3,259>2.0195)$ sehingga ada pengaruh persepsi guru atas kepemimpinan kepala sekolah (X1) terhadap kinerja guru sebesar 0,495 pada konstanta 26,259.

2. Pengujian hipotesis parsial dengan pendekatan uji t menunjukkan bahwa besarnya $t_{\text {hitung }}>t_{\text {tabel }}(3,390>2.0195)$, sehingga ada pengaruh kesejahteraan (X2) terhadap kinerja guru sebesar 0,261 pada konstanta 26,259.

3. Pengujian hipotesis simultan dengan pendekatan uji $\mathrm{F}$ menunjukkan bahwa besarnya $F_{\text {hitung }}>F_{\text {tabel }}(16,626>3,23)$, sehingga persepsi guru atas kepemimpinan kepala sekolah (X1) dan kesejahteraan (X2) secara bersama sama berpengaruh terhadap kinerja guru dengan persamaan regresi $\widehat{\mathbf{Y}}=26,259+$ $0,495 X_{1}+0,261 X_{2}$.

4. Koefisien determinai $\left(\mathrm{R}^{2}\right)$ dalam penelitian ini sebesar 0,448 artinya bahwa variabel persepsi guru atas kepemimpinan kepala sekolah (X1) dan kesejahteraan (X2) mampu menjelaskan perubahan kinerja guru sebesar 44,8\% sedangkan sisanya sebesar 55,2\% dijelaskan oleh variabel lain yang tidak dihipotesiskan pada penelitian ini.

\section{DAFTAR PUSTAKA}

Budhihadjo, Andreas. 2011. Organisasi Menuju Pencapaian Kinerja Optimum. Jakarta : Prasetya Mulya Publishing

Gibson, Jamaes L. John M. Invancevich, James H. Donelly, 2005, Organization : Close-Up, Texas Business Publication

Gerungan, W.A, 2006, Psikologi Sosial. Bandung : Refika Aditama.

Hamka. 2002. Psikologi Pendidikan, Jakarta : Rieneka Cipta

Hapsari, Iriani Indri dan Ira Puspitawati, 2004, Psikologi Faal.Bandung : Rosda Karya 
Hasibuan, M.S.P. 1992. Personal Administration and Human Resources. Jakarta: Gunung Agung.

Herawan, Endang dan Nani Hartini. 2013. Manajemen Pendidikan : Manajemen Tenaga Pendidik dan Kependidikan. Jakarta : Tim Dosen Administrasi Pendidikan Universitas Pendidikan Indonesia, Alfabeta

Indarafachrudi, Soekarto 2003, Mengatur Bagaimana Memimpin Sekolah yang Baik, Jakarta : Ghalia Indonesia

Indarafachrudi, Soekarto. 2006. Bagaimana Memimpin Sekolah yang Efektif. Bogor: Ghalia Indonesia

Khan, Shafique Ali. 2005. Filsafat Pendidikan Al-Ghazali Gagasan Konsep Teori dan Filsafat Ghazali Mengenai Pendidikan, Pengetahuan dan Belajar, Bandung : Pustaka Setia.

Maier. 2002. Personal Adminstrasion and Human Resources. Jakarta : Gunung Agung.

Mangkunegara, Anwar Prabu. Manajemen Sumber Daya Manusia Perusahaan. Bandung : Remaja Rosda Karya

Mar'at, 2001. Sikap Manusia Perubahan Serta Pengukurannya. Jakarta: Ghalia Indonesia.

Nawawi, Hadari, 1993. Kepemimpinan Menurut Islam, Yogyakarta : Gajah Mada University Press.

Peraturan Pemerintah Republik Indonesia No. 19 tahun 2005

Pusat Bahasa Departemen Pendidikan Nasional, 2008. Kamus Besar Bahasa Indonesia, Jakarta : Pusat Bahasa.

Robbins, P Stephen, 2003. Organizational Behavior. USA : Prentice Hall Internasionall, Inc.

Robbins, P Stephen dan Timothy A Judge, 2015. Perilaku Organisasi, Jakarta : Salemba Empat

Sirait, T Justine. 2006. Memahami Aspek-Aspek Pengelolaan Sumber Daya Manusia dalam Organisasi. Jakarta : Grasindo

Sunyoto, Danang. 2013. Teori Kuesioner dan Proses Analisis Data Perilaku Organisasional, Yogyakarta : Center for Academic Publishing Service (CAPS). 
Suwarto. 2010. Perilaku Keorganisasian. Yogyakarta : Penerbit Universitas Atmajaya

Thoha, Miftah, 2003. Kepemimpinan Dalam Manajemen, Jakarta: PT Raja Grafindo.

Ukas, Maman. 2004. Manajemen. Bandung: Agini

Uno, H. Hamzah B. 2008.Profesi kependidikan. Problema, Solusi dan Reformasi Pendidikan di Indonesia.Jakarta : Bumi Aksara. 